\title{
Gen İdentifikasyonu ve DNA Kütüphanelerinin Oluşturulması
}

\author{
Gülseren Yıldız Öz ${ }^{1}$, Vahdettin Altunok² \\ ${ }^{1}$ Pendik Veteriner Kontrol Enstitüsü, İstanbul \\ ${ }^{2}$ Selçuk Üniversitesi Veteriner Fakültesi Biyokimya AD, Konya
}

Geliş Tarihi / Received: 09.02.2016, Kabul Tarihi / Accepted: 30.05.2016

\begin{abstract}
Özet: Genetik çalışmalar 1865 yılında Gregor Mendel tarafından başlatılmıştır. Günümüzde de tüm dünyada bilim adamları tarafından büyük bir hızla devam ettirilmektedir. Genetik bir çalışma, üzerinde çalışılacak gen bölgesinin izolasyonu ile başlamaktadır. Bir gen bir kere izole edildikten sonra o gen üzerinde yapılacak işlemlerin sınırı yoktur. DNA ve RNA düzeyinde yapılan genetik çalışmalarda, genler tek başına ya da genlerin birbirleri ile olan etkileşimleri incelenerek tedavi yöntemleri geliştirilmeye çalışılmaktadır. Bilim adamları, izole edilen genler veya DNA parçaları için saklama yöntemleri araştırmaktadır. Bu yöntemlerden biri de DNA kütüphanesi oluşturmaktır. DNA kütüphanelerinin kurulmasıyla, kütüphanelerdeki kitaplar gibi DNA koleksiyonu ve deposunun oluşturulması amaçlanmaktadır. DNA kütüphaneleri; kanserde, nöroloji ve göz hastalıkları gibi alanlarda gen tedavisi çalışmalarında kullanılmaktadır. Ayrıca, rekombinant ilaçların bulunmasında, besin maddesi olarak ihtiyaç duyulan bazı proteinlerin üretilmesinde, çeşitli genlerin moleküler düzeyde tanımlandığı biyoteknolojik çalışmalarda, gen izolasyonu ve DNA kütüphanesi oluşturma yöntemine başvurulmaktadır.
\end{abstract}

Anahtar kelimeler: DNA kütüphanesi, gen izolasyonu, klonlama

\section{Gene Identification and Construction of DNA Libraries}

\begin{abstract}
Genetic studies were firstly started in 1865 by Gregor Mendel. Also the studies are continued at a great pace by the scientists on the world. A genetic study starts by isolation of the studied gene from the whole genom. When a gene is isolated from DNA, there is no limit of transactions on the gen. In the genetic studies on DNA and RNA have been studied the genes are single or genes interact with each other analyze and the treatment methods to developing. In present researches study on preserving methods of isolated genes or DNA fragments. One of these methods is to constitute a library of the DNA. It is aimed to collection and archive the DNA in a DNA library by similar the books on the library. DNA libraries are frequently utilized for gene therapy in oncology, neurology, eye diseases and etc. Furthermore, method of DNA libraries are used in recombinant pharmaceutical manufacturing, production of some proteins as a nutritient and in biotechnological studies that different genes are defined on molecular level.
\end{abstract}

Key words: DNA library, gene isolation, clonning

\section{Giriş}

Günümüzde kalıtımın esas fonksiyonel ünitesi olan, bir polipeptidi kodlayan kromozomal DNA dizisi olarak tanımlanan gen kavramı, ilk olarak 1865 yılında Gregor MENDEL tarafından ortaya çıkartılmıştır. Mendel, yaptığg hibritleme çalışmalarında ebeveynlerden yeni döllere aktarılan bazı karakteristik özelliklerin olduğuna dikkat çekmiştir [7]. Bu tarihten sonra genlerin bir nesilden diğerine geçişi, genlerin fiziksel yapıları, genlerdeki varyasyonlar ve genlerin bir türün özellikleri üzerindeki etki yolları tüm dünyadaki bilim adamları tarafından araştırılmaya başlanmıştır [14].

Genetik alanında biyoteknolojik çalışmalar yürütülürken birtakım zorluklarla karşılaşılmaktadır.
Genetik bir çalışmanın başlangıcı, üzerinde çalış1lacak gen bölgesinin izolasyonu ile yapılmaktadır. Daha sonra bu gen bölgesi üzerinde çeşitli metotlarla farklı işlemler uygulanmaktadır. Uzun bir gen bölgesi üzerinde yapılan çalışmalarda DNA'nın küçük parçalara ayrılarak çalışılmasının daha pratik olacağ1 düşünülmektedir. Örneğin; insan genom uzunluğu 3 milyar 289 milyon bp uzunluğundadır ve yaklaşık 25 bin gen kodlar. Genetik kusuru olan ya da ilgilenilen DNA kısmını bulmak, samanlıkta iğne aramak gibidir. DNA'nın manipüle edilebilecek büyüklükte kısımlara ayrılarak çalışılması, her seferinde DNA'nın diğer kısımlarıyla uğraşma zorunluluğunu ortadan kaldıracaktır [8]. Ayrıca göz hastalıkları gibi birden fazla genin kontrolünde oluşan hastalık sebeplerinin moleküler düzeyde araştı- 
rilması gerekmektedir. DNA ve RNA düzeyinde yapılan bu çalışmalarda, hastalıkla ilgisi olduğu düşünülen genler izole edilerek ve genlerin birbirleri ile etkileşimleri moleküler düzeyde incelenerek tedavi yöntemleri geliştirilmeye çalışılmaktadır [6].

DNA'nın manipüle edilecek kısımlara ayrılarak saklanması işlemi DNA kütüphanelerinin oluşturulması ile mümkün olabilmektedir. DNA kütüphanelerinin oluşturulması için ilk basamak ilgilenilen gen bölgesinin diğer DNA kısımlarından ayrımlanmasıdır. DNA'yı manipüle edebilmek için iki çeşit gen izolasyon tekniği kullanılır: ilki, her alanda yaygın olarak kullanılan PCR (Polimeraz Zincir Reaksiyonu) tekniğidir. Bu işlem saf gen numunesini elde etmek için kullanılabilir. Primerler ilgili genin her iki tarafına bağlanabilirse genin birçok kopyası sentezlenebilir $[5,13]$. Gen izolasyonunda kullanılan diğer bir işlem gen klonlama yöntemidir. $\mathrm{Bu}$ işlem, ilgilenilen gen bölgesinin vektör denilen halkasal bir DNA molekülüne sokulması ve vektörün bir konakçıya aktarılması ile gerçekleştirilmektedir. Vektör molekülü konak hücrede genin sayısız kopyalarını üretir ve üretilen kopya DNA molekülleri döllere geçer. Bu şekilde oluşan çok sayıda kopyadan sonra özdeş konağın bir kolonisi üretilmiş olur. Bu işlem tüm genoma yapılırsa o DNA'ya ait değişik koloniler yani DNA kütüphaneleri oluşturulmuş olur [8]. İzole edilen bir gen üzerinde yapilabilecek işlemlerin sınırı yoktur. Mevcut teknolojik şartların izin verdiği ölçüde araştırmalar yapılmaktadır. İzole edilen genler veya DNA parçaları için saklama yöntemi geliştirildiğinde ise gelecekte var olacak yeni teknolojilerle de çalışmalara faklı boyutlarda devam edilebilecektir. Geçmişte yaşayan insanlar, ölen kişileri mumyalayarak korumaya, sonraki nesillere aktarabilmek için saklamaya çalışmışlardır. Gelişen teknolojiyle birlikte günümüzde mumyalama işlemine benzer şekilde kişilerin DNA'ları saklanmaya çalışılmaktadır. Sadece insanlar için değil, hayvanlar, bitkiler, hastalık etkenleri ve daha birçok canlı DNA'sı için saklama yöntemleri geliştirilmiştir. Bu amaçla geliştirilen yöntemlerden biri de DNA kütüphaneleri oluşturmaktır.

\section{Gen izolasyonu ve DNA kütüphanelerinin oluşturulması}

DNA kütüphanesi; saflaştırma, saklama ve analiz kolaylığı için bir vektör içine klonlanmış her bir organizmaya ait farklı DNA sekansları koleksiyo- nu olarak tanımlanabilmektedir. DNA kütüphanesi oluşturabilmek için öncelikle DNA'nın ilgili dokudan izole edilmesi gereklidir. DNA'nın ortamdaki diğer moleküllerden ayrımlanarak izolasyon işlemi tamamlandiktan sonra DNA derişimleri ultraviyole absorbans spektrofotometresi ile hassas olarak ölçülebilir [10]. İzole edilen DNA'ya ilk manipülatif girişim, DNA'nın küçük parçalara ayrılması işlemidir. DNA'nın restriksiyon enzimleri ile parçalara ayrı1masının ardından DNA parçalarının jel elektroforezde yürütülmesi ve otoradyografi ile görüntülenmesi sağlanır [4]. Hedeflenen gen bölgesinden DNA'nın geri kazanımı için jelden gen bölgesinin izolasyonu işlemi gerçekleştirilir. DNA geri kazanımı için geliştirilmiş yöntemlere, ticari olarak üretilen küçük "sepharacyl” kolonlarla yapılan saflaştırma, düşük sıcaklıkta eriyebilen agaroz kullanılarak saflaştırma, elektroelüsyon ve "gene clean" yöntemi örnek olarak gösterilebilir [12]. Bu yöntemlerle istenilen boyuttaki DNA fragmanını saf olarak elde etmek ve DNA'yı herhangi bir aşamada saflaştırmak olasıdır.

Restriksiyon enzimleri ile kesilen bu küçük DNA parçalarının her biri uygun bir vektöre klonlanır. Hedef bölgenin elde edilmesinin ardından gen kütüphanesi yapımında istenen verimin sağlanabilmesinde kullanılacak vektör seçimi önemli yer tutmaktadır. Vektörler doğal ya da yapay olabilirler. Doğal vektörlerden biri, bakteri içerisinde çok sayıda bulunan ve hem bakteri DNA'sı hem de diğer hemcinsleri ile uyumlu yaşayan plazmit DNA'sıdır. Diğer bir doğal vektör ise bakterileri enfekte eden ve bir bakteri kültüründe koloninin etrafindan bolca izole edilebilen faj DNA'sıdır. Bunların haricinde yapay vektör olarak, üzerlerinde oynanarak yetenekleri daha uzun DNA parçalarını içerecek şekilde geliştirilen yapay kromozomlar oluşturulmuştur. Bunlara örnek olarak; BAC (Bakteri Yapay Kromozomu), YAC (Maya Yapay Kromozomu), MAC (Memeli Yapay Kromozomu), HAC (İnsan Yapay Kromozomu), PAC (P1 Yapay Kromozomu) verilebilir [4,11].

Vektör DNA'sının izolasyonunun ardından DNA kütüphanelerinin oluşturulmasında önemli basamaklardan biri de vektör molekülü ve klonlanacak olan DNA molekülünün birbirine bağlanmasıyla gerçekleştirilen ligasyon işlemidir. Kullanılan vektöre göre konakçıya nakil işlemi ise farklılık göstermektedir. Plazmit ve bakteriyofajın konakçı- 
ya nakli rekombinant vektörün konakçıya naklinin gerçekleştiği işlem basamağına örnek olarak gösterilmektedir [4].

Bir sonraki işlem basamağı olarak, rekombinant vektörü içine alan konakçının tespit edilmesi gereklidir. Hangilerinin rekombinant, hangilerinin kendi kendine bağlanan vektör molekülleri içerdikleri, inaktive edilen gen tarafindan kodlanan özellik artık konak tarafından sergilenmediği için saptanabilir.

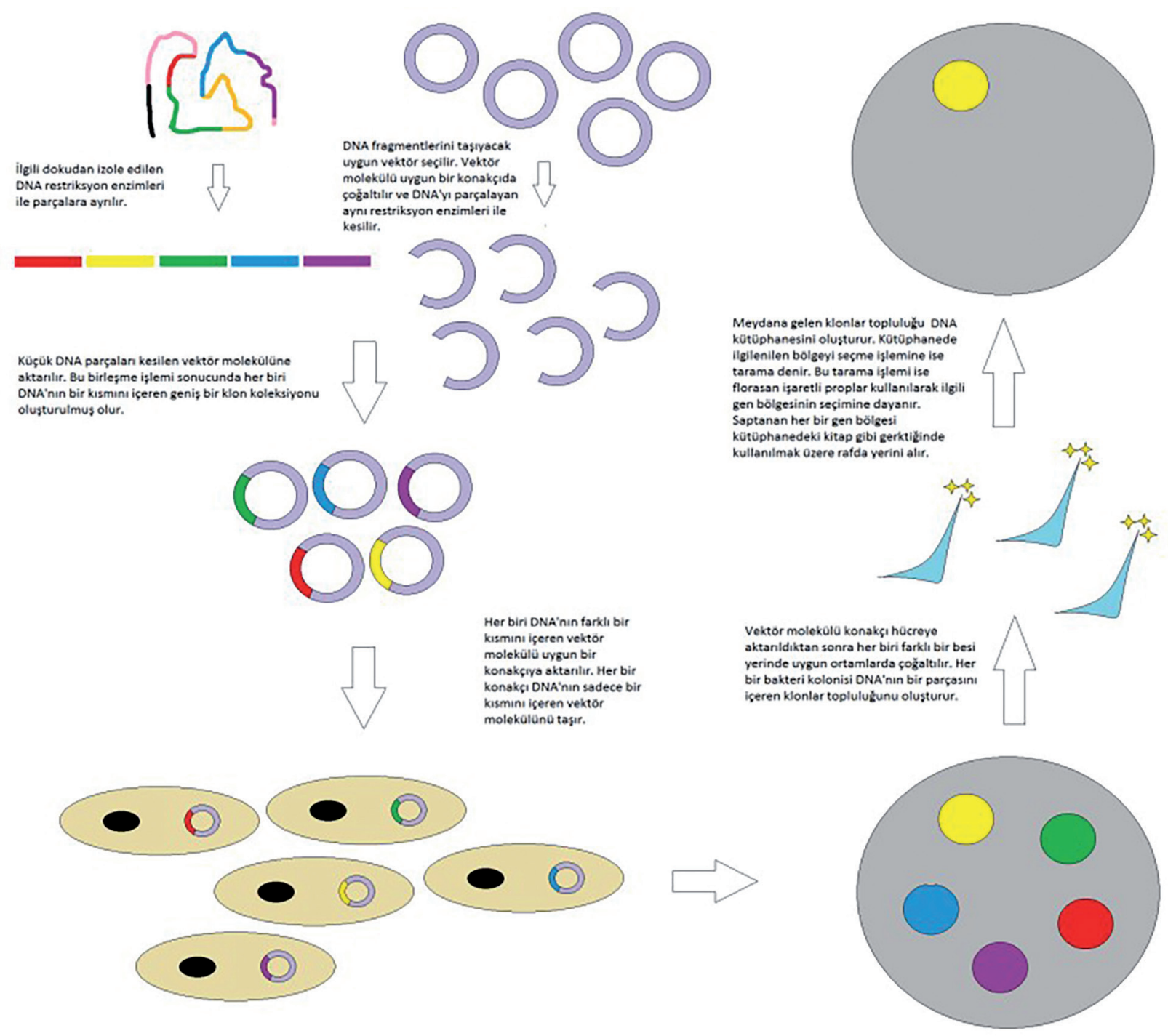

Şekil 1. Gen izolasyonu ve DNA kütüphanesi oluşturulması işlemi basamakları

Mevcut bir kütüphaneden yaralanarak veya kütüphane oluşturulduktan sonra çalışmalara başlanabilmesi için ilgili gen bölgesinin yerinin saptanması gerekir. Bu amaçla kütüphaneler taranır. Klonlamanın doğrulanması için klonlanan genin DNA sekansının belirlenmesi önemlidir. Kütüphanenin saklanmasından önce kütüphane tit- resi hesaplama ve kütüphane ebatı belirleme işlemleri yapilır $[1,3,8,15]$

Tüm bu işlemlerin sonunda her biri DNA'nın bir kısmını içeren geniș bir klon koleksiyonu oluşur. Her biri DNA'nın ayrı bir parçasını içeren vektörler, farklı uygun konakçılara aktarılır. Konakçılar uygun bir ortamda büyütülür. Büyüyen her kolo- 
ni DNA'nın özel bir kısmının klonlarını içerir. Bu klonlar kütüphanedeki kitaplar gibidir, ancak kütüphanedeki gibi indekse sahip değildir. Kütüphaneden ilgilenilen bölgeyi seçme işlemine "tarama" (screening) denir, bu da en önemli ve son basamaktır. $\mathrm{Bu}$ aşamada, klonlanan genin tespiti kütüphanenin taranması ile yapılır. Klonlanan genin DNA sekans1 belirlenerek klonlamanın doğrulanması sağlanır. Bu işlemler sonucunda elde edilen gen, gerekli durumlarda izole edilip kullanılmak amacıyla gen kütüphanelerinde depolanır.

Bir DNA kütüphanesi bahsedildiği gibi basit bir şekilde kurulabilir. Gen kütüphanesi oluşturulurken nasıl bir başlangıç materyali kullanıldığı ise önemli bir değerlendirmedir. Kullanılan DNA'nın elde ediliş şekline göre iki şekilde kütüphane oluşturulabilmektedir. Kromozomal DNA'nın izole edilip, restriksiyon enzimleri ile kesilmesi ve takip eden diğer işlemler sonucunda klonlanması ile genomik kütüphaneler oluşturulmaktadır. İlgili dokudan mRNA'nın izole edilip, sonrasında cDNA sentezlettirilmesi ve cDNA'nın klonlanması ile sonuçlanan işlemde ise cDNA kütüphaneleri oluşturulmaktadır.

Gen bölgesinin aktarımında kullanılan vektöre göre kütüphaneler değişik isimlerle adlandırılabilmektedir. Örneğin; DNA fragmanlarını konakçıya aktarmak amaciyla vektör olarak maya yapay kromozomunu kullanılmış ise, kütüphane YAC (maya yapay kromozomu) kütüphanesi olarak isimlendirilmektedir [4].

\section{Oluşturulmuş bir kütüphanenin kullanım alanlarından bazıları;}

Bir gen izole edilip bir kez klonlandıktan sonra o gen üzerinde yapılabilecek işlemlerin, araştırmaların sınırı yoktur. Birçok alanda değişik organizmalarla çalışılmaktadır. Araştırmacılar bakteri, parazit, virüs ya da daha büyük organizmalar ile çalışabilir. Çalışılan genin izole edilmesi, çalışılan alanı daraltır. Bu da araştırmacıya zaman ve enerji tasarrufu sağlar. Ayrıca izole edilen bu gen bölgesi ya da tüm genom, tekrar aynı kişi veya başka araştırmacılar tarafından kullanılmak istenebilir. Örneğin; teknolojinin hızla ilerlediği içinde bulunduğumuz zamanlarda, Türkiye'de yapılan bir araştırma sonucu tespit edilen bir gen bölgesi internette yayınlanarak, bunun dünyanın diğer ucundaki araştırıcılar tarafından kullanılması sağlanabilir. Buna benzer amaçlarla organizmaların genleri izole edilmeye çalışılır. Her gen ayrı bir fonksiyon üstlenir ve araştırıcılar tarafindan bu fonksiyonlar kullanılarak yeni moleküller üretilmeye çalış1lır. Bu sayede hastalıklara çare olacak ilaçlar, aşılar ve hormonlar sentezlettirilir [4].

Günümüzdeki canlılara ait DNA bilgileri, gen kütüphaneleri yardımı ile sonraki nesillere aktarılarak geleceğe 1 şı tutulabilir. İnsanların çeşme yaptırıp bunu sonraki nesillere aktararak, yardımseverliğin ölümsüzleştirilmek istendiği düşünüldügünde, DNA kütüphanesi hazırlanarak gelecekte yaşayacak insanlara çeşme örneğinden çok daha fazla yardımc1 olabileceği söylenebilir.

İnsan nüfusunun artışıyla birlikte, besinsel ihtiyaçlar da artmakta, bu da hayvansal ve bitkisel üretimin arttırılması zorunluluğunu meydana getirmektedir. Bitki ve hayvanların genetiği değiştirilerek, gen eklenip çıkartılarak onların verimleri arttırılmaya çalışılmaktadır. GDO'lu bitkiler ve broiler tavuklar genetiği değiştirilmiş canlılara örnek gösterilebilir [2,9]

Oluşturulmuş bir DNA kütüphanesi bir kitap gibidir. Bilim ve teknolojideki gelişmeleri dikkate alarak, yeni her türlü imkandan yararlanmak ve yeni buluşlar kazandırmak için DNA üzerinde çalışmalar yapılır. Çalışmak için izole edilen bu DNA'ların bir kitap gibi saklanması, ihtiyaç olarak görülür. Hastalıklar ve hastalık etkenleri açısından değerlendirildiğinde, sorunlu genlerin keşfedilmesi, mutasyonlu bölgelerin bakım ve onarımının yapılabilmesi, tedavi yöntemlerinin geliştirilebilmesi gibi daha birçok amaçla oluşturulan DNA kütüphanelerine, günümüzde olduğu kadar gelecekte de ihtiyaç duyulacağ 1 bir gerçektir.

\section{Kaynaklar}

1. Alwine JC, Kemp DJ, Stark GR, (1977). Method for detection of specific RNAs in agarose gels by transfer to diazobenzyloxymethyl-paper and hybridization with DNA probes. Proc Natl Acad Sci, 74 12, 5350-5354.

2. Babaoğlu M, (1999). Bitkilerde gen transferi teknikleri. Ziraat Yüksek Mühendisleri Birliği Dergisi, 322, 24-26.

3. Bhattacharya SS., Wright AF., Clayton JF., Price WH., Philips CI., McKeown CME., Jay M., Bird AC., Pearson PL., Southern EM., Evans HJ., 1984. Close genetic linkage between $\mathrm{X}$-linked retinitis pigmentosa and a restriction fragment length polymorphism identified by recombinant DNA probe L1.28. Nature, 309, 253-255. 
4. Brown TA, (2009). Gen klonlama ve DNA analizi (gene cloning\& DNA analysis, an introduction). Beşinci Baskıdan Çeviri. Nobel Yayın Dağıtım, Ankara.

5. Chen BY, Janes HW, (2002). PCR clonning protocols. 2. Edition, New Jersey, Human Pres.

6. Güran Ş, (2011). Moleküler biyoloji ve genetikteki gelişmelerin 1şığında göz hastalıklarında ileri tanı ve tedavi. Gülhane T1p Dergisi, 53, 74-76.

7. Huang Z, Petty JT, O'Quinn B, Longmire JL, Brown NC, Jett JH, Keller RA, (1996). Large DNA fragment sizing by flow cytometry: application to the characterization of P1 artificial chromosome (PAC) clones. Nucleic Acids Research, 24 (21), 4202- 4209.

8. Jodge J, Lund PA, Minchin S, (2007). Gene cloning, principles and applications. NewYork, Taylor\&Francis Group, 85-116.

9. Kumlay AM, Dursun A, (2003). Bitki genetik mühendisliği ve ekonomik öneme sahip bazı bitkilerde genetik mühen- disliği uygulamaları. Atatürk Üniv Ziraat Fak Derg, 34 (2), 209-216.

10. Lluch MC, Jofre J, Muniesa M, (2011). Antibiotic resistance genes in the bacteriophage DNA fraction of enviromental samples. Plos one, 6 3:e17549.

11. Lüleyap HÜ, (2008). Moleküler genetiğin esasları. Birinci Bask1. Nobel kitabevi, Adana.

12. Temizkan G, Arda N, (1999). Moleküler biyolojide kullanılan yöntemler. İkinci Baskı. Nobel T1p Kitabevleri, İstanbul.

13. Türkyılmaz S, Esendal ÖM, (2002). Polimeraz zincir reaksyonu ve mikrobiyolojide kullanım alanları. Kafkas Üniv Vet Fak Derg, 8 (1), 71-76.

14. Ulutin T, (2005). İnsan genom projesi. Moleküler Hematoloji ve Sitogenetik Alt Komitesi, Temel Moleküler Hematoloji Kursu. 70-72, Mersin, Türkiye.

15. Yıldırım A, Kandemir N, Karadağ Y, Sakin MA, (2010). Genetik. İkinci Baskı. Nobel Yayın Dağıtım, Ankara. 